\title{
OnabotulinumtoxinA for Hemicrania Continua: open label experience in 9 patients
}

\author{
Sarah Miller ${ }^{1}$, Fernando Correia ${ }^{1,2}$, Susie Lagrata ${ }^{1}$ and Manjit S Matharu ${ }^{1 *}$
}

\begin{abstract}
Background: Hemicrania continua is a strictly unilateral, continuous headache, typically mild to moderate in severity, with severe exacerbations commonly accompanied by cranial autonomic features and migrainous symptoms. It is exquisitely responsive to Indomethacin. However, some patients cannot tolerate treatment, often due to gastrointestinal side effects. Therapeutic alternatives are limited and controlled evidence lacking.

Methods: We present our experience of nine patients treated with OnabotulinumtoxinA for hemicrania continua. All patients were injected using the PREEMPT (Phase 3 REsearch Evaluating Migraine Prophylaxis Therapy) protocol for migraine.

Results: Five of nine patients demonstrated a $50 \%$ or more reduction in moderate to severe headache days with OnabotulinumtoxinA with a median reduction in moderate to severe headache days of $80 \%$. Patient estimate of response was $80 \%$ or more in five subjects. The median and mean duration of response in the five responders was 11 and 12 weeks (range 6-20 weeks). Improvements were also seen in headache-associated disability
\end{abstract}

Conclusions: OnabotulinumtoxinA adds a potential option to the limited therapeutic alternatives available in hemicrania continua.

Keywords: Botulinum toxin-A; Hemicrania continua; Treatment; Indomethacin

\section{Background}

Hemicrania continua $(\mathrm{HC})$ is a strictly unilateral, continuous headache that is exquisitely responsive to Indomethacin [1]. It is more prevalent in women and usually begins in adulthood $[2,3]$. The pain is typically of mild to moderate intensity and often involves the forehead, temporal, orbital and occipital regions [3]. Exacerbations of pain are seen in the majority and are commonly accompanied by cranial autonomic features and migrainous symptoms $[2,3]$.

Hemicrania continua is, by definition, exquisitely responsive to Indomethacin [1]. Despite the efficacy of Indomethacin in $\mathrm{HC}$, more than $30 \%$ of patients experience adverse effects and $20 \%$ have to discontinue the drug [4]. Finding possible therapeutic alternatives to Indomethacin is, thus, of great clinical relevance.

Several other drugs have been reported to be at least partially effective in open-label reports including:

\footnotetext{
* Correspondence: m.matharu@uclmail.net

${ }^{1}$ Headache Group, Institute of Neurology and The National Hospital for Neurology and Neurosurgery Queen Square, London WC1N 3BG, UK Full list of author information is available at the end of the article
}

cyclooxygenase-2 inhibitors, aspirin, ibuprofen, naproxen, topiramate, melatonin, valproic acid, gabapentin, verapamil and methylprednisolone. Other options are greater occipital nerve blocks (GONB) and neuromodulation. However, none appear to be as effective as Indomethacin.

Even though the exact mechanism of action of OnabotulinumtoxinA (BoNT-A) remains unclear, it is thought to involve multiple mechanisms. Theories include inhibition of neurotransmitter release from motor and sensory nociceptive neurons resulting in interruption of the inflammatory loop promoting peripheral and central sensitization or direct inhibition of central sensitization in the CNS, via axonal transport [5].

The efficacy of BoNT-A in chronic migraine prophylaxis is now well established [6]. Experience in trigeminal autonomic cephalalgias (TACs) is scarce; experience in 14 cluster headache and one Short-lasting Unilateral Neuralgiform Headache with Conjunctival Injection and Tearing (SUNCT) patients have been published [7-11]. In $\mathrm{HC}$, there are two single subject case reports on the use of BoNT-A [12,13]. In the first case, painless 
autonomic attacks continued, whereas in the second case, autonomic features fully resolved. In this open label study we examine the outcome of nine patients undergoing BoNT-A treatment for $\mathrm{HC}$.

\section{Methods}

Patients receiving BoNT-A with the Headache Group at the National Hospital for Neurology and Neurosurgery were analyzed. Patients were diagnosed with $\mathrm{HC}$ in accordance to International Classification of Headache Disorder criteria (ICHD-3beta) [1]. All had unilateral headaches that had responded fully to an indomethacin trial (oral or intramuscular trials, detailed in Table 1). All patients were injected with BoNT-A as per the Phase 3 REsearch Evaluating Migraine Prophylaxis Therapy (PREEMPT) regime for chronic migraine, with patients having a modified regime (exclusion of occipital and cervical paraspinal sites) if they had an occipital nerve stimulator (ONS) in situ [6].

All data was collected prospectively with the use of headache diaries. Average monthly scores were calculated from a month pre-treatment and a three-month post-final treatment diary. Headache days were recorded as any day on which the subject recorded $\mathrm{HC}$ pain. Subjects were asked to score pain intensity on two scales: 1) pain free, mild, moderate and severe; and 2) verbal rating scale (VRS). Headache load (HAL) was calculated from diaries using the formula: $\Sigma$ (severity (VRS) $\times$ pain duration (hours). Disability scores consisting of Headache Impact Test (HIT-6), Migraine Disability Assessment (MIDAS) and Hospital Anxiety and Depression scale (HAD) were collected before and after treatment.

Responders to treatment were classified as those achieving a $50 \%$ or greater improvement in headache days rated as moderate to severe. Other outcomes included those achieving a $30 \%$ and $50 \%$ or greater improvement in HAL and $30 \%$ or more improvement in headache days rated as moderate to severe.

Median values pre- and post-treatment were compared using Wilcoxon Signed Ranks tests and a statistically significant result set at the $95 \%$ level $(\mathrm{p}=0.05)$. Data was processed using IBM SPSS Version 22 for Windows.

The study was approved by Northwick Park Hospital Research Ethics Committee, Hampstead, London, and written consent obtained from all patients.

\section{Results}

A total of nine patients with $\mathrm{HC}$ received treatment with BoNT-A, of whom six were females and three males (see Table 1). Median age at time of treatment was 48 years (19-61 years) and median duration of $\mathrm{HC}$ was 8 years (1-34 years). During exacerbations, migrainous features were present in six and autonomic features in all subjects. Three patients reported visual auras during exacerbations.
Four patients had concomitant episodic migraine (EM) and one co-existent idiopathic stabbing headache. All patients were able to differentiate their co-existent headaches from $\mathrm{HC}$ and none of the co-existent headaches had responded to indomethacin trials.

Subjects had failed to respond to a median of seven previous treatments for $\mathrm{HC}$. Two subjects had failed to respond to ONS and one was awaiting ONS implantation.

Reasons for treatment with BoNT-A are summarized in Table 1. Eight patients could not tolerate therapeutic doses of indomethacin due to gastro-intestinal (GI) side effects. Two patients complained of worsening of their EM with indomethacin doses required to suppress HC. Patients had a median of two treatments (range 2-6) with a median BoNT-A dose of 167 units (range 110-185 units) injected at each treatment.

The results of BoNT-A treatment are summarized in Table 2. Five subjects demonstrated a response of $50 \%$ or more in reduction of moderate or severe headache days to mild headache days or pain free and were classified as responders to treatment. Six subjects reported a $30 \%$ or greater response in reduction of moderate or severe headache days to mild headache days or pain free. The median reduction in total headache days was $90 \%$ (range $0-100)(\mathrm{p}=0.026)$ and in moderate to severe headache days $80 \%$ (range $0-100)(\mathrm{p}=0.012)$. Headache load showed a median improvement of $62 \%$ (range $0-100$ ) with six patients demonstrating a $30 \%$ and $50 \%$ or more improvement. Significant improvements were also seen in average headache hours and average VRS (Table 2). The median subjective duration of response in the five responders post treatment was 11 weeks (range 6-20 weeks, mean 12 weeks). Five subjects reported a subjective benefit of $80 \%$ or more in their HC.

Four subjects were taking indomethacin prior to BoNT-A and all were able to stop regular use after treatment with two using indomethacin as required at a frequency of less than three times a month.

Headache disability scores showed a trend to improvement after BoNT-A (Table 3). HIT-6 showed a median change of 12 points $(\mathrm{p}=0.069)$. This is above the threepoint change suggestive of minimal clinical difference. MIDAS improved by a median of 51 points $(\mathrm{p}=0.063)$.

Adverse events were reported in three subjects: one eyebrow ptosis, one frontalis over-activity and one transient worsening in headache before improvement was noted. All adverse events were rated as mild by patients and transient in nature.

\section{Discussion}

This series is the largest so far of BoNT-A treatment for HC. Five out of nine patients showed a greater than $50 \%$ reduction in moderate or severe headache days to mild headache days or pain free with a median reduction in 
Table 1 Demographic details of patients and treatment

\begin{tabular}{|c|c|c|c|c|c|c|c|c|c|c|c|c|}
\hline & \multirow[t]{2}{*}{ Sex } & \multirow{2}{*}{$\begin{array}{l}\text { Age at } \\
\text { treatment } \\
\text { (years) }\end{array}$} & \multirow{2}{*}{$\begin{array}{l}\text { Duration of } \mathrm{HC} \\
\text { at treatment } \\
\text { (years) }\end{array}$} & \multicolumn{3}{|c|}{ Phenotype of HC } & \multirow{2}{*}{$\begin{array}{l}\text { Indomethacin } \\
\text { dose required } \\
\text { to suppress HC }\end{array}$} & \multirow{2}{*}{$\begin{array}{l}\text { Co-existent } \\
\text { headache }\end{array}$} & \multirow{2}{*}{$\begin{array}{l}\text { Previous } \\
\text { number of } \\
\text { treatments } \\
\text { trialled }\end{array}$} & \multirow{2}{*}{$\begin{array}{l}\text { Reasons for administering } \\
\text { BoNT-A }\end{array}$} & \multirow{2}{*}{$\begin{array}{l}\text { No of } \\
\text { sessions } \\
\text { of BoNT-A } \\
\text { treatments }\end{array}$} & \multirow{2}{*}{$\begin{array}{l}\text { Average } \\
\text { units } \\
\text { injected }\end{array}$} \\
\hline & & & & Location & $\begin{array}{l}\text { Autonomic } \\
\text { symptoms }\end{array}$ & $\begin{array}{l}\text { Migrainous } \\
\text { symptoms }^{\mp}\end{array}$ & & & & & & \\
\hline 1 & $M$ & 19 & 1 & Right & Yes & $\mathrm{Nil}$ & 225 mg daily & $\begin{array}{l}\text { EMWOA } \\
\text { (Bilateral) }\end{array}$ & 4 & $\begin{array}{l}\text { Worsening EM on } \\
\text { Indometacin }\end{array}$ & 4 & 168 \\
\hline 2 & $\mathrm{~F}$ & 61 & 1 & Left & Yes & Yes Visual Aura & 150 mg daily & Nil & 4 & Gl-upset & 3 & 165 \\
\hline 3 & M & 59 & 12 & Right & Yes & $\mathrm{Nil}$ & $\begin{array}{l}\text { IM Indometacin } \\
\text { test** }\end{array}$ & Nil & 13 & $\begin{array}{l}\text { Unable tolerate Indometacin; } \\
\text { Refractory to other treatments; } \\
\text { ONS in-situ }\end{array}$ & 2 & 175 \\
\hline 4 & M & 48 & 2 & Right & Yes & $\begin{array}{l}\text { Yes Visual Aura } \\
\text { (occasional) }\end{array}$ & 150 mg daily & $\begin{array}{l}\text { EMWA (bilateral, } \\
\text { once month) }\end{array}$ & 9 & $\begin{array}{l}\text { Gl-upset; peptic ulcer disease; } \\
\text { refractory to other treatments - } \\
\text { awaiting ONS }\end{array}$ & 2 & 165 \\
\hline 5 & $\mathrm{~F}$ & 47 & 9 & Right & Yes & Yes & 225 mg daily & $\begin{array}{l}\text { Past EMWOA } \\
\text { (stopped 2004) }\end{array}$ & 3 & Gl-upset & 5 & 167 \\
\hline 6 & $\mathrm{~F}$ & 49 & 34 & Right & Yes & Yes & 150 mg daily & $\begin{array}{l}\text { EMWA (bilateral, } \\
\text { once month) }\end{array}$ & 6 & $\begin{array}{l}\text { Gl-upset; refractory to other } \\
\text { treatments; ONS in-situ }\end{array}$ & 2 & 110 \\
\hline 7 & $\mathrm{~F}$ & 48 & 18 & Left & Yes & Yes & $\begin{array}{l}\text { IM Indometacin } \\
\text { test** }\end{array}$ & $\mathrm{ISH}$ & 13 & Gl-upset & 2 & 155 \\
\hline 8 & $\mathrm{~F}$ & 41 & 8 & Right & Yes & No Visual Aura & 150 mg daily & $\begin{array}{l}\text { EMWOA (side } \\
\text { variable/bilateral) }\end{array}$ & 7 & $\begin{array}{l}\text { Gl-upset; wheeze; dizziness; } \\
\text { worsening EM }\end{array}$ & 6 & 168 \\
\hline 9 & $\mathrm{~F}$ & 54 & 4 & Right & Yes & Yes & 225 mg daily & Nil & 9 & Gl-upset & 2 & 185 \\
\hline Mean & & 47 & 10 & & & & & & 8 & & 3 & 162 \\
\hline $\begin{array}{l}\text { Median } \\
\text { (Range) }\end{array}$ & & $48(19-61)$ & $8(1-34)$ & & & & & & $7(3-13)$ & & $2(2-6)$ & $167(110-185)$ \\
\hline
\end{tabular}

M, Male; F, Female; HC, Hemicrania continua; EMWA, Episodic migraine with aura; EMWOA, Episodic migraine without aura ISH, Idiopathic stabbing headache; BoNT-A, OnabotulinumtoxinA; Gl, Gastrointenstinal; ONS, Occipital nerve stimulator; IQR, Inter-quartile range; 'Autonomic symptoms including ptosis, lacrimation, conjunctival injection, meiosis, nasal blockage, rhinorrhea, facial redness, facial sweating, eyelid oedema, restlessness; ${ }^{\mp}$ Migrainous symptoms including nausea, vomiting, photophobia, phonophobia, osmophobia, motion sensitivity; **IM Indometacin test blinded placebo test of 100 mg IM Indometacin v normal saline. 
Table 2 Headache scores pre- and post- treatment with OnabotulinumtoxinA

\begin{tabular}{|c|c|c|c|c|c|c|c|c|c|c|c|c|c|c|c|}
\hline \multirow[t]{2}{*}{ ID } & \multicolumn{3}{|c|}{ Average headache days/month } & \multicolumn{3}{|c|}{ Average moderate -severe days/month* } & \multicolumn{3}{|c|}{ Average daily headache hours } & \multicolumn{3}{|c|}{ Average daily VRS } & \multirow{2}{*}{$\begin{array}{l}\text { Change in } \\
\text { headache } \\
\text { load (\%) }\end{array}$} & \multirow{2}{*}{$\begin{array}{l}\text { Subjective } \\
\text { estimate of } \\
\text { response }\end{array}$} & \multirow{2}{*}{$\begin{array}{l}\text { Estimated } \\
\text { duration of } \\
\text { response } \\
\text { (weeks) }\end{array}$} \\
\hline & Pre & Post & Change \% & Pre & Post & Change \% & Pre & Post & Change $\%$ & Pre & Post & Change $\%$ & & & \\
\hline 1 & 30 & 0 & 100 & 20 & 0 & 100 & 24 & 0 & 100 & 5 & 0 & 100 & 100 & $>90 \%$ & 16 \\
\hline 2 & 30 & 0 & 100 & 15 & 0 & 100 & 24 & 0 & 100 & 5 & 0 & 100 & 100 & $>90 \%$ & 20 \\
\hline 3 & 30 & 30 & 0 & 30 & 19 & 37 & 24 & 24 & 0 & 8 & 6 & 25 & 20 & $30-50 \%$ & 5 \\
\hline 4 & 30 & 30 & 0 & 30 & 30 & 0 & 24 & 24 & 0 & 7 & 6 & 14 & 0 & 0 & 0 \\
\hline 5 & 30 & 3 & 90 & 30 & 3 & 90 & 24 & 6 & 75 & 7 & 10 & 0 & 98 & 80-90\% & 12 \\
\hline 6 & 30 & 30 & 0 & 30 & 23 & 23 & 15 & 16 & 0 & 7 & 6 & 14 & 0 & $15-25 \%$ & 4 \\
\hline 7 & 30 & 22 & 27 & 21 & 13 & 27 & 24 & 7 & 71 & 7 & 4 & 43 & 55 & $40 \%$ & 6 \\
\hline 8 & 30 & 2 & 93 & 30 & 0 & 100 & 24 & 8 & 67 & 9 & 2 & 78 & 99 & 80-90\% & 6 \\
\hline 9 & 30 & 0 & 100 & 30 & 0 & 100 & 24 & 0 & 100 & 8 & 0 & 100 & 100 & $>90 \%$ & 9 \\
\hline Mean & 30 & 13 & 57 & 25 & 10 & 64 & 23 & 9 & 57 & 7 & 4 & 51 & 62 & & 8 \\
\hline $\begin{array}{l}\text { Median } \\
\text { (Range) }\end{array}$ & $30(30)$ & $3(0-30)$ & $90(0-100)$ & $30(15-30)$ & $3(0-30)$ & $80(0-100)$ & $24(15-24)$ & $7(0-24)$ & $71(0-100)$ & $7(5-9)$ & $4(0-10)$ & $43(0-100)$ & $98(0-100)$ & & $6(0-20)$ \\
\hline
\end{tabular}

*Response defined as 50\% or more improvement in average moderate-severe headache days/month; VRS, Verbal Rating Scale; Pre, Pre-treatment; Post, Post-final treatment. 
Table 3 Headache-associated disability scores pre- and post- treatment with OnabotulinumtoxinA

\begin{tabular}{|c|c|c|c|c|c|c|c|c|c|c|c|c|}
\hline \multirow[t]{2}{*}{ ID } & \multicolumn{3}{|l|}{ HIT-6 } & \multicolumn{3}{|l|}{ MIDAS } & \multicolumn{3}{|l|}{ HAD-A } & \multicolumn{3}{|l|}{ HAD-D } \\
\hline & Pre & Post & $\begin{array}{l}\text { Change } \\
\text { in score }\end{array}$ & Pre & Post & $\begin{array}{l}\text { Change } \\
\text { in score }\end{array}$ & Pre & Post & $\begin{array}{l}\text { Change } \\
\text { in score }\end{array}$ & Pre & Post & $\begin{array}{l}\text { Change } \\
\text { in score }\end{array}$ \\
\hline 1 & 65 & 58 & 7 & 73 & 0 & 73 & 10 & 8 & 2 & 9 & 3 & 6 \\
\hline 2 & 57 & 36 & 21 & 24 & 0 & 24 & 1 & 0 & 1 & 0 & 0 & 0 \\
\hline 3 & 56 & 68 & -12 & 52 & 52 & 0 & 3 & 9 & -6 & 2 & 12 & -10 \\
\hline 4 & 68 & 67 & 1 & 105 & 130 & -25 & 12 & 6 & 6 & 10 & 8 & 2 \\
\hline 5 & 67 & 44 & 23 & 120 & 0 & 120 & 9 & 2 & 7 & 9 & 1 & 8 \\
\hline 6 & 63 & 60 & 3 & 121 & 13 & 108 & 16 & 18 & -2 & 15 & 15 & 0 \\
\hline 7 & 63 & 54 & 9 & 24 & 13 & 9 & 2 & 3 & -1 & 5 & 7 & -2 \\
\hline 8 & 64 & 62 & 2 & 240 & 4 & 236 & 0 & 0 & 0 & 3 & 0 & 3 \\
\hline 9 & 76 & 24 & 52 & 51 & 0 & 51 & 12 & 0 & 12 & 4 & 0 & 4 \\
\hline Mean & 64 & 53 & 12 & 90 & 24 & 66 & 7 & 5 & 2 & 6 & 5 & 1 \\
\hline $\begin{array}{l}\text { Median } \\
\text { (Range) }\end{array}$ & $64(56-76)$ & $58(24-68)$ & $7(-12$ to 52$)$ & $73(24-240)$ & $4(0-130)$ & $51(-25$ to 236$)$ & $9(0-16)$ & $3(0-18)$ & $1(-6$ to 12$)$ & $5(0-15)$ & $3(0-15)$ & $2(-10$ to 8$)$ \\
\hline
\end{tabular}

Post-final treatment. 
moderate and severe days of $80 \%$. All four subjects taking daily indomethacin prior to treatment were able to stop regular use. Five patients reporting an $80 \%$ or more improvement in their $\mathrm{HC}$ and clinically significant improvements were seen in both HIT-6 and MIDAS.

The patient group had tried a median of seven previous preventatives and had suffered from $\mathrm{HC}$ for a median of 8 years at the time of BoNT-A treatment. The refractory nature of the group means that it is doubtful that our observations are due to spontaneous remission. Despite four patients reporting co-existing episodic migraine, all were clearly able to differentiate this from their $\mathrm{HC}$. The phenotype of $\mathrm{HC}$ was secure in all subjects and all meet ICHD-3beta criteria including a complete response of their side-locked headache to an adequate indometacin trial. Although a number of subjects report migrainous symptoms associated with $\mathrm{HC}$, this is an accepted feature commented on in epidemiological studies and the ICHD3beta criteria [1,3]. Given that all patients were carefully phenotyped and could clearly differentiate their episodic migraine attacks from hemicrania continua taken together with the sparse evidence for the efficacy of botulinum toxin in episodic migraine, our data are consistent with a change in $\mathrm{HC}$ and not the co-existent episodic migraine.

This series is still small, and this must be considered when interpreting the results. Previous studies of BoNT-A have reported a significant placebo response and we cannot eliminate this as a potential confounding factor in our outcomes. However, the relatively high response rates taken together with the consistent efficacy of repeated BoNT-A injections and a mean duration of effect similar to that seen in other reports in TAC as well as chronic migraine suggest that the response to BoNT-A in this series cannot be attributed entirely to the placebo response $[10,12,13]$.

The exact mechanisms by which BoNT-A produces therapeutic benefit remains unclear, but the neurotoxin is likely to function by multiple mechanisms, suppressing events associated with peripheral and central sensitization. Both migraine and TACs are believed to share a common pathophysiology comprising of the activation of the trigeminovascular system and involvement of neuroactive peptides such as calcitonin gene-related peptide (CGRP), vasoactive peptide (VIP) and glutamate [14]. Animal studies have provided evidence of BoNT-A suppressing nociception in peripheral trigeminovascular neurons and also suppressing CGRP and VIP release from these neurons [5] There is also data to support the hypothesis that the toxin may act via central mechanisms with studies showing retrograde axonal transport of active BoNT-A $[15,16]$. The potential target of BoNT$\mathrm{A}$ in chronic migraine is the direct blockage of trigeminal neurons providing nociception to the head and face. Suppression of neuro-inflammatory mediator release leads to decreased activation of second-order neurons within the trigemino-cervical complex and brainstem. BoNT-A may therefore be assumed to exert its benefit by repressing the neuro-inflammatory mediators responsible for the maintenance of peripheral and central sensitization $[17,18]$. It is therefore possible that BoNT-A has a wider therapeutic potential than chronic migraine. It is interesting to speculate that the clinical and functional imaging similarities between migraine and $\mathrm{HC}$ may mean that BoNT-A has more of an impact in $\mathrm{HC}$ than the other TACs which are much more clinically distinct to migraine [19].

\section{Conclusion}

OnabotulinumtoxinA may be a promising alternative to Indomethacin in patients with $\mathrm{HC}$ who do not tolerate the drug. Treatment appears to be associated with a significant improvement in moderate to severe headache days and related disability. It may add another potential therapeutic agent for $\mathrm{HC}$ to the limited number available. However, further controlled studies are necessary to clarify the efficacy of BoNT-A in HC.

\section{Competing interests}

SM has received educational grants from St Jude Medical and Medtronic and has received payment for educational presentations from Allergan. FC has no competing interests. SL has received payment for educational sessions from Allergan. MSM serves on the advisory board for Allergan and St Jude Medical, and has received payment for the development of educational presentations from Allergan, Merck Sharpe and Dohme Ltd and Medtronic.

\section{Authors' contributions}

SM carried out data collection and analysis and drafted the manuscript. FC helped to collect data and draft the manuscript. SL carried out data collection and helped to draft the manuscript. MSM conceived the study, phenotyped the patients and participated in data collection and interpretation and revising the manuscript. All authors read and approved the final manuscript.

\section{Author details}

${ }^{1}$ Headache Group, Institute of Neurology and The National Hospital for Neurology and Neurosurgery Queen Square, London WC1N 3BG, UK. ${ }^{2}$ Department of Neurology, Centro Hospitalar do Porto, Oporto, Portugal.

Received: 20 January 2015 Accepted: 16 February 2015

Published online: 05 March 2015

\section{References}

1. Headache Classification Committee of the International Headache S (2013) The International Classification of Headache Disorders, 3rd edition (beta version). Cephalalgia 33(9):629-808, PubMed

2. Peres MF, Silberstein SD, Nahmias S, Shechter AL, Youssef I, Rozen TD et al (2001) Hemicrania continua is not that rare. Neurology 25(6):948-951, PubMed

3. Cittadini E, Goadsby PJ (2010) Hemicrania continua: a clinical study of 39 patients with diagnostic implications. Brain 133(Pt 7):1973-1986, PubMed Epub 2010/06/19. eng

4. Dodick DW (2004) Indomethacin-responsive headache syndromes. Curr Pain Headache Rep 8(1):19-26, PubMed

5. Durham PL, Cady R (2011) Insights into the mechanism of onabotulinumtoxinA in chronic migraine. Headache 51(10):1573-1577, PubMed Pubmed Central PMCID: 3306767. Epub 2011/11/16. eng

6. Dodick DW, Turkel CC, DeGryse RE, Aurora SK, Silberstein SD, Lipton RB et al (2010) OnabotulinumtoxinA for treatment of chronic migraine: pooled results from the double-blind, randomized, placebo-controlled phases of the PREEMPT clinical program. Headache 50(6):921-936, PubMed Epub 2010/05/22. eng 
7. Robbins L (2001) Botulinum Toxin A (Botox) for cluster headache: 6 cases. Cephalalgia 21:492-503

8. Smuts JA, Barnard PWA (2000) Botulinum toxin type A in the treatment of headache syndromes: a clinical report on 79 patients. Cephalalgia 20:332-337

9. Sostak P, Krause P, Forderreuther S, Reinisch V, Straube A (2007) Botulinum toxin type-A therapy in cluster headache: an open study. J Headache Pain 8 (4):236-241, PubMed Epub 2007/09/29. eng

10. Freund BJ, Schwartz M (2000) The use of Botulinum toxin-A in the treatment of refractory cluster headache: case reports. Cephalalgia 20:235-331

11. Zabalza RJ (2012) Sustained response to botulinum toxin in SUNCT syndrome. Cephalalgia 32(11):869-872, PubMed Epub 2012/06/27. eng

12. Garza I, Cutrer FM (2010) Pain relief and persistence of dysautonomic features in a patient with hemicrania continua responsive to botulinum toxin type A. Cephalalgia 30(4):500-503, PubMed Epub 2009/06/12. eng

13. Khalil M, Ahmed F (2013) Hemicrania continua responsive to botulinum toxin type a: a case report. Headache 53(5):831-833, PubMed Epub 2013/03/29. eng

14. May A, Goadsby PJ (1999) The trigeminovascular system in humans: pathophysiologic implications for primary headache syndromes of the neural influences on the cerebral circulation. J Cereb Blood Flow Metab 19(2):115-127, PubMed Epub 1999/02/23. eng

15. Matak I, Bach-Rojecky L, Filipovic B, Lackovic Z (2011) Behavioral and immunohistochemical evidence for central antinociceptive activity of botulinum toxin A. Neuroscience 186:201-207

16. Meng J, Ovsepian SV, Wang J, Pickering M, Sasse A, Aoki KR et al (2009) Activation of TRPV1 mediates calcitonin gene-related peptide release, which excites trigeminal sensory neurons and is attenuated by a retargeted botulinum toxin with anti-nociceptive potential. J Neurosci 29(15):4981-4992

17. Aoki KR (2003) Evidence for antinociceptive activity of botulinum toxin type A in pain management. Headache 43(Suppl 1):S9-S15

18. Seybold VS (2009) The role of peptides in central sensitization. Handb Exp Pharmacol 194:451-491

19. Matharu MS, Cohen AS, McGonigle DJ, Ward N, Frackowiak RS, Goadsby PJ (2004) Posterior hypothalamic and brainstem activation in hemicrania continua. Headache 44(8):747-761, PubMed Epub 2004/08/28. eng

\section{Submit your manuscript to a SpringerOpen ${ }^{\circ}$ journal and benefit from:}

- Convenient online submission

- Rigorous peer review

- Immediate publication on acceptance

- Open access: articles freely available online

- High visibility within the field

- Retaining the copyright to your article

Submit your next manuscript at $\gg$ springeropen.com 